\title{
Media Reputation of the Insurance Industry: An Urgent Call for Strategic Communication Management
}

\author{
Robert G. Eccles and Matthias Vollbracht \\ Media Tenor Deutschland GmbH, Am Kurpark 71, Bonn 53173, Germany. \\ E-mail: m.vollbracht@medientenor.de
}

The power of the media has become a parameter for business success in recent years, as media reality - the image of reality that is created by the media - has become a key factor influencing all of a company's stakeholders. These include customers, suppliers, employees, politicians, regulators and the general public. Based on a long-term analysis of German media coverage (1998-2006) and an international comparative analysis of media coverage in the U.K., France, Spain, Italy, Austria, the U.S. and Asia (2004/2005), the following article outlines the changing reputational risk environment regarding the insurance industry. This analysis shows why companies must take a proactive stance on corporate communications. This is confirmed by the experience of Media Tenor, an international media research and consulting institute and Perception Partners Inc., a consulting firm specializing in reputational risk.

The Geneva Papers (2006) 31, 395-408. doi:10.1057/palgrave.gpp.2510086

Keywords: reputation management; insurance; media coverage Spitzer; value reporting; trust

\section{Introduction}

For many years, insurance companies were of little interest to the opinion-leading news media, standing in the shadow of more prominent industries such as automotive, banking and information technology. As long as everything was going reasonably well in the insurance industry, it was a comfortable place to be from a communication's standpoint: to communicate or not to communicate, either was fine.

However, those days are gone forever. Insurance companies, whose very existence is about taking on risk, now face a very special risk of their own: reputational risk. This has recently been felt through breathtaking litigation and investigations such as those by Spitzer into long-accepted business models regarding relationships between insurance companies and their brokers. The result is that insurance companies must now take a very proactive stance on communications lest others determine what their reputation will be. This involves constantly monitoring what is being said about them and by whom in order to identify areas of vulnerability that need to be addressed.

The following article describes the fundamental change in media reporting regarding insurers that took place in the German market for the period between 1996 and 2006. These findings are supported by an analysis of the differences in media reporting in a variety of international markets such as the U.K., France, Italy and the U.S. in 2004/ 2005. Finally, it assesses the extent to which information being supplied by insurance 


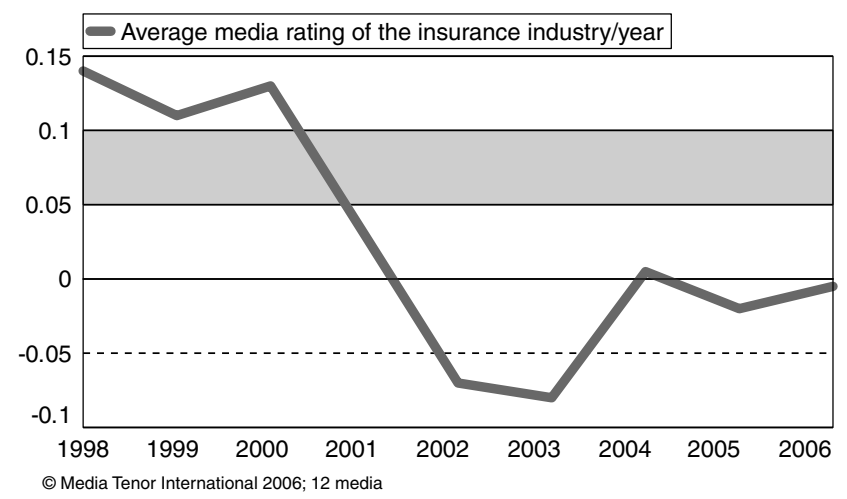

Chart 1. Media rating of insurance industry in German media during 01/1998-01/2006.

companies is sufficient to maintain a balanced media reputation incorporating the concept of ValueReporting ${ }^{\mathrm{T}, 1}$ to build and maintain public trust. ${ }^{2}$

\section{Through hell and back - the image of the insurance industry in the German media 1998-2006}

\section{General industry trend}

After a long period of sustained growth following the Second World War, the German insurance industry garnered increased public awareness in the 1990s with German reunification: Allianz took over Deutsche Versicherung, the former East German public insurer. At the same time, the German market became more international with German insurers taking over foreign companies (such as Allianz-AGF from France) and foreign companies such as Generali from Italy expanded their reach into the German market (e.g., buying AMB). However, a disturbing political issue eclipsed these commercial activities as German banks and insurers were confronted with claims related to their Nazi history.

Nevertheless, despite the claims of Holocaust victims and their heirs, the media image of the insurance industry was rather positive. Chart 1 displays the media rating balance of the insurance industry in the opinion-leading German dailies, weeklies and TV news channels. An average rating of 0.1 or higher defines a clearly positive rating and trustable image. (The 0.1 threshold marks the minimum requirement for a trusted image.) Between 1998 and 2000, the overall rating of the industry was rather favourable and the stock market rally boosted insurers' reserves, especially for those that were heavily weighted in equities in their investment portfolio. However, this positive period ended with the triple burden of the $09 / 11$ terrorist attacks, major natural disasters in 2002 and the stock market crash of 2002/2003, which led to large

\footnotetext{
${ }^{1}$ Eccles et al. (2003).

${ }^{2}$ DiPiazza and Eccles (2002).
} 
losses for the industry. During this period, the average rating balance declined to only 0.03 in 2001 and fell to unparalleled lows in 2002/2003 by going into the negative range.

Since insurance is all about trust, the media image of the insurance industry is critical to its viability. These negative ratings created a real public trust crisis for some companies such as Mannheimer and Gerling. These two well-known and trusted brands did not survive this pressure on their traditional structure. The life insurance unit of Mannheimer collapsed ${ }^{3}$ and Protector, a hive-off vehicle created by the industry, had to take over around 344,000 client policies. ${ }^{4}$ The Frankfurter Allgemeine Zeitung (FAZ) ${ }^{5}$ reported that Gerling lost its equity capital in 2002. Chart 1 shows that although the industry has largely recovered broadly from its financial losses of several years ago, the media rating of the industry has not, thereby leaving it vulnerable to reputational risk.

\section{Regulators are going public}

For most of the past, the German insurance industry has managed to keep regulatory issues out of the media. Business results and products were the primary source of critical media reporting, although negative issues regarding these reputation criteria did not dominate the media image and were mostly compensated for by positive reports on the same issues. This has changed: the crisis at Mannheimer and Gerling and declining equity capital and financial reserves have brought the question of effective industry regulation onto the media's agenda. The newly created Bundesanstalt für Finanzdienstleistungsaufsicht (BaFin), a result of the merger of Bundesaufsichtsamt für das Versicherungswesen (BaV), Kreditwesen (BaKred) and Wertpapierhandel (BaWe) has not hesitated to take a more aggressive approach in addressing industry issues. While the three institutions $\mathrm{BaV}$, BaKred and $\mathrm{BaWe}$ together achieved a volume of 73 mentions in Germany's most important national daily FAZ in 2001, the BaFin garnered 185 mentions in 2003, the first year after it was established.

A more accurate analysis of the drivers of negative coverage of the insurance industry points to the core reputation risks in Germany: during 1998-2000 products, results and the claims linked to the Third Reich (Politics/Regulation/Society in Chart 2) displayed the major threats for the industry. Between 2001 and 2003, it was the loss of financial reserves by declining results or even losses and depreciation of their assets, especially stockholdings in other companies, which deprived some insurers of their capability to do what an insurer is meant to do: stand in when other shelters have perished. Since 2004, the rebound of the stock market combined with restructuring programmes has shifted media awareness to other fields of risk, especially products, management and litigation/scandals. Litigation/scandals (not displayed in Chart 2) made up hardly 5 per cent of all negative coverage on the insurance industry in Germany in 2003. However, since 2004 German media have closely followed the

\footnotetext{
${ }^{3}$ Financial Times Deutschland (2003, p. 10).

${ }^{4}$ Stuttgarter Zeitung (2003, p. 10).

${ }^{5}$ Frankfurter Allgemeine Zeitung (2003, p. 13).
} 


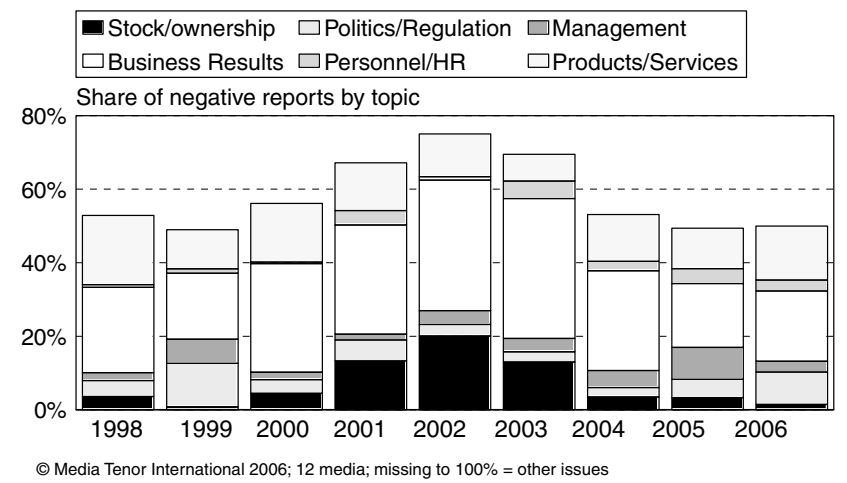

Chart 2. Negative media rating of the insurance industry in German media by topics.

attacks by New York State Attorney General Eliot Spitzer against insurance industry icons such as insurer AIG and insurance broker Marsh and McLennan and subpoenas sent to other companies such as Munich Re by Spitzer and the SEC. ${ }^{6}$ The share of negative reporting linked to image and scandals has consequently skyrocketed to 17 per cent in 2004 and 26 per cent in 2005.

There are some serious hints that litigation and lawsuits brought against German insurance companies will pose an increasing reputational risk. One reason is the global structure of many insurance and reinsurance companies, which gives plaintiffs the opportunity to take their case to a U.S. court where they think they will get a more favourable reception and settlement. Another reason is that companies have become more concerned about reputation threats from lawsuits, which are often accompanied by an aggressive media strategy. ${ }^{7}$

\section{Balancing shareholders' and other stakeholders' interests}

Schanz ${ }^{8}$ has described the "three broad dimensions that influence a company's longterm performance: (a) its access to resources; (b) its position within the industry structure and (c) the socio-political environment." While the globalization and deregulation of the financial markets have increased companies' capability to source and offer services on a worldwide basis, the industry structure and the socio-political environment represent rather challenging tasks, especially when it comes to the media. Thanks to the proliferation of media sources and the many ways in which people can get access to this information on a real-time basis (e.g., TV, mobile phones, PDAs, etc.), "media reality" has become more real than the underlying reality itself.

Using as an example the reporting about industry structure, a strong market position can be framed in a positive ("leadership") or negative ("dominance") way.

\footnotetext{
${ }^{6}$ Insurance, Finance and Investment (2005).

${ }^{7}$ Handelsblatt (2005, p. 26).

${ }^{8}$ Schanz (2004).
} 


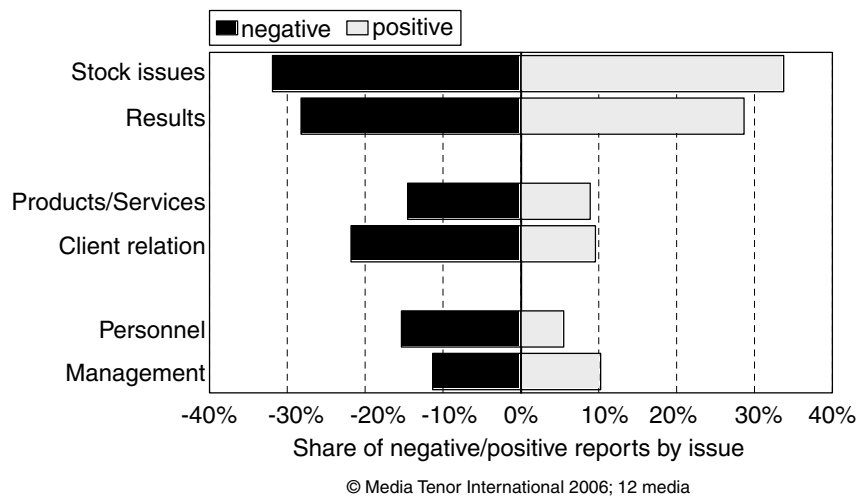

Chart 3. Positive/negative reporting on the insurance industry in German media during 1998-2006.

Although actual market share might be the same in both cases, the dominant media frame can make a relevant difference to whether the authorities approve a merger/ takeover or not. Given the recent industry troubles, consumers might favour strong businesses (leaders) over smaller and potentially weaker ones if the companies successfully communicate the advantages of their size. However, if the media, for whatever reasons, are framing large market share as industry "dominance," then consumers and regulators will be more likely to have an unfavourable view.

Turning to the dimension of the socio-political environment, the importance of "media reality" has been recognized by political institutions and regulators. They have become very sophisticated in making a media strategy a basic part of their overall political, rule-making and enforcement activities. This marks a notable break with attitudes in the past.

The socio-political environment also includes other stakeholders like NGOs, which are not directly involved with the company but which have garnered significant influence in recent years in Germany and around the world. While the focus of NGOs in the 1980s and 1990s lay more on environmental issues, peace and human rights, groups that focus on consumer interests and on the downsides of the economic globalization such as $\operatorname{Attac}^{9}$ have increased in importance and visibility. In 2004, Attac's visibility in the business sections of opinion-leading German dailies was twothirds that of the NGO icon Greenpeace.

Schanz argues in his article cited above that a company's access to resources (including shareholders/owners, clients and employees) is the primary value driver of long-term performance. Chart 3 shows a balanced media picture for results and the shareholder resource component in terms of "stock issues." However, when it comes to the other two resources critical for performance, clients and employees, the media picture is an alarming one: client relations and personnel are both portrayed in a largely negative way, as are products and services. Blaming journalists for only focusing on negative issues is not enough to explain this critical image. Instead, the

\footnotetext{
${ }^{9}$ Association pour la Taxation des Transactions pour l'Aide aux Citoyens.
} 
failure of companies to adapt proactive communication strategies, which focus on the key determinants of long-term performance, is as much a factor as any inherent media bias.

\section{Learning from the German market}

The long-term analysis of the insurance industry's media reputation in Germany has described three different phases in recent years: (1) a low-key, positive media environment in the 1990s; (2) reputation crises in 2001-2003 as a result of depletion of capital and a lack of proactive communication; and (3) the period of stabilization since 2004 with insurers garnering increasingly positive reporting on business results and stock prices but facing new challenges from reports about litigation and a lack of customer and employee focus. As the media in Germany rediscover their role as advocates of consumers and employees and as regulators more aggressively use the media to address their concerns, insurance companies must expect these challenges to remain perilous for the future.

\section{Media reputation of the insurance industry in cross-country comparison}

\section{Methodology}

Although the insurance and reinsurance business is a fairly international one, media reporting varies substantially by country. Thus, managing reputation in different media environments is crucial for building and sustaining an overall trusted image. The following analysis is based on the coverage of the insurance industry in the news and business sections of between 28 (Germany) and two (Asia) publications in 2005 with a total of 70,168 reports about companies and senior executives. The coverage was analysed using a range of 3,100 different topics (e.g., stock price, earnings, products) that were aggregated into 21 image criteria. The selected publications represent opinion-leading, broadsheet publications rather than the trade press.

\section{U.S. and U.K. market coverage driven by litigation and scandals}

Although the tone of coverage in reporting about companies in the U.S. is generally more positive compared to the European continent, the Spitzer investigations into the insurance industry and high exposure to major natural damages such as hurricanes Andrew and Katrina have resulted in a rather negative current image of the U.S. insurance industry. A share of nearly 40 per cent of negative ratings represents a fundamental challenge for an insurer's reputation. Recent analysis by Media Tenor has shown that the insurance industry - contrary to the banks - was ill-prepared for even one of these major events. ${ }^{10}$ A major reason can be explained by the concept of the "Awareness Threshold." The Awareness Threshold is the level of media awareness at which individual negative stories and/or actions do not have a significant negative effect. When a company is below the Awareness Threshold, there is also no support for positive news and actions that occur to boost sales, HR, IR, etc. Although the

\footnotetext{
${ }^{10}$ Vollbracht (2005, pp. 50-51).
} 
specific "Awareness Threshold" has to be determined by comparing polls and media reporting in each individual market, a share of less than 3 per cent of all coverage on the industry usually leads to a situation where the company is unknown to the broader public and thus at risk from events that could substantially damage its reputation. In most of the markets analysed for this article, the 3 per cent benchmark was surpassed by only four to five companies.

In contrast to insurance companies, banks have an ongoing basic visibility in the media with research on stocks, sectors and markets as well as comments on individual companies. Additionally, the media frequently reports on the results, products and strategy of banks because of their central role in the capital markets. Such substantial neutral or even positive reporting on the expertise of the banks has helped to outweigh many negative stories linked to litigation and scandals in recent years. However, the insurance industry - although it employs numerous think tanks doing substantial research ranging from stocks to the development of markets and risks - has long been reluctant to make use of these assets for boosting its daily media coverage and thus creating brand awareness and some protection against negative news (Chart 4).

Similarly, the U.K. press, already critical of the industry, became even more so after picking up on the Spitzer allegations.

Media coverage of the insurance industry in Italy was again shaped largely by the takeover battle for BNL, with Unipol insurance trying to defend foreign bids from Dutch ABN Amro and Spanish BBVA. The media heavily reported the claims of foreign companies that Unipol did not play a fair game. Overall, Unipol coverage made up for one-third of all reports on the insurance industry in 2005. The media reporting on most other companies was rather positive, for example on RAS or Generali as well as on smaller players such as Lloyd Adriatico, that were praised for strong results, healthy stock price gains and innovative products.

Positive reporting in the French press was driven by favourable business results (e.g., AGF, Axa) as well as by reports about new fields of business such as private additional health insurance. The Austrian press painted the most favourable picture of the insurance industry, despite flood-related claims. Overall, the expansion of Austrian insurers and banks in Eastern Europe was frequently picked up by the media and a

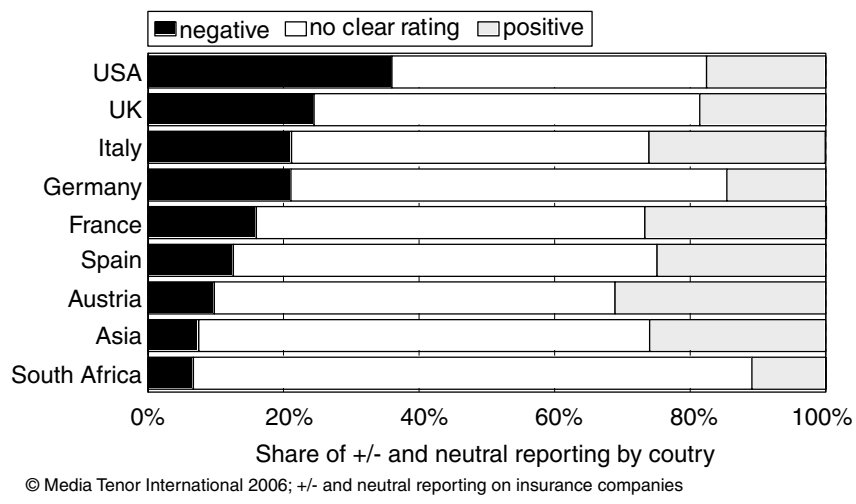

Chart 4. Positive/negative reporting on the insurance industry in international media in 2005. 
constant source of positive reporting. Insurance companies managed to garner a significant share of media awareness for $\mathrm{P} \& \mathrm{C}$ and life insurance as well.

The opinion-leading Spanish media such as Expansion or El Mundo intensively reported about the fierce competition between domestic and foreign insurers to increase their market share in the car insurance business. However, they also took a closer look at international players such as Allianz and Axa, as Mapfre tried to expand their international reach. Overall, the media image of the insurance industry in Spain was rather positive as healthy results and growth figures outweighed negative reports on major natural damage claims or "imported" negative stories such as the Spitzer allegations.

\section{Surfing the agenda}

Addressing the right issues is as important as the tone of coverage for communication risk management and reputation monitoring. By selecting some news and not selecting others, journalists constantly build a media agenda. Through filtering some issues and stressing others, the media shapes its own autonomous reality that may differ substantially from the underlying reality of events. The concentration on a few issues makes the audience recognize those issues and subjects as more important than other issues. As Bernhard Cohen states: "The mass media may not be successful much of the time in telling people what to think, but the media are stunningly successful in telling their audience what to think about."11

From a reputation management perspective, it is crucial to closely monitor the media agenda and to address it in a way that journalists are offered additional information on subjects they consider particularly relevant. For example, journalists do not constantly report about business activities in other countries to the same extent. At one point in time, the media might be focused on one country, such as China, and then some months later, it might shift its attention to India. A company that is aware of these changes might provide the journalists with additional information on their business in China or India at the right time. This can result in positive stories highlighting expertise, growth potential or management vision with regard to these issues in a balanced way in all countries of interest to the company.

Operating in an international context also means understanding different media agendas simultaneously. Unlike politicians, companies can hardly ever set an agenda in the media, but instead must "surf" the existing trends of reporting. Companies need to be aware of what the media is interested in and provide stories addressing the relevant issues from their point of view. At the margin, companies can influence the media agenda usually more by adding topics to it than by taking them off. Stock prices and shareholder value-related issues accounted for 20.5 per cent of all reports in the South African press in 2005 , while those topics contributed to only 6.5 per cent in the U.S. If the media do not pay too much attention to stock market-related issues, the media image has to be shaped with reports from companies to increase its attention here.

Personalization of news coverage is a significant trend in all Western publications in recent years. The share of reports focusing predominantly on management was highest

\footnotetext{
${ }^{11}$ Cohen (1963)
} 


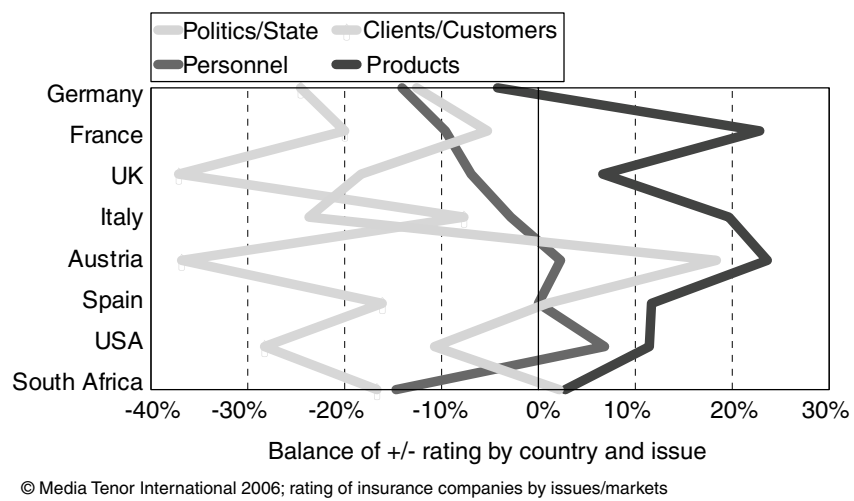

Chart 5. Rating of the insurance industry in international media in 2005 by issue.

in the U.K. (13.3 per cent) and the U.S. (13.1 per cent) and rather low in South Africa (4.8 per cent) and Italy (7.7 per cent). This means communication managers in the U.K. and U.S. not only have to deliver stories and facts but also - more than in other markets - the people behind the facts.

A key aspect of reputation building is successful communication of products and the business model. Regarding the investor side, Media Tenor research has shown that a consistent product communication is a clear indicator for midterm (70-90 days) stock performance. Regarding the customer side, the positive thing about neutral or favourable product coverage is that it has a higher credibility compared to advertising. If a company is successful in pitching a story on a new and probably innovative insurance product to an opinion-leading media outlet, other media usually will pick up on this story as well. The introduction of assistance products (insurance products that offer help/service instead of or in addition to financial compensation) in Germany last year is an example of this.

In cross-country comparisons, Austrian and German media focused most on products (19.9 per cent and 16.3 per cent, respectively). Actively communicating about products has another positive effect: on balance journalists will report more often about products and services in a positive way than not, even if they sometimes highlight critical issues. A major weakness in all markets is the lack of positive examples of customer focus. While most recently the media reported on excellent financial results, journalists in surveys highlighted at the same time a need for more client and employee orientation by the companies, which is very consistent with the negative reporting on client/customer-related issues and the small amount of coverage (Chart 5).

\section{Managing the reputation of the insurance industry by "ValueReporting"}

\section{What do the media currently deliver and what do they not?}

Rebuilding public trust with regard to shareholders, clients, employees and a broader public is closely connected with communication of the factors which create value in the industry. However, this is not only about disclosure procedures but also about the 


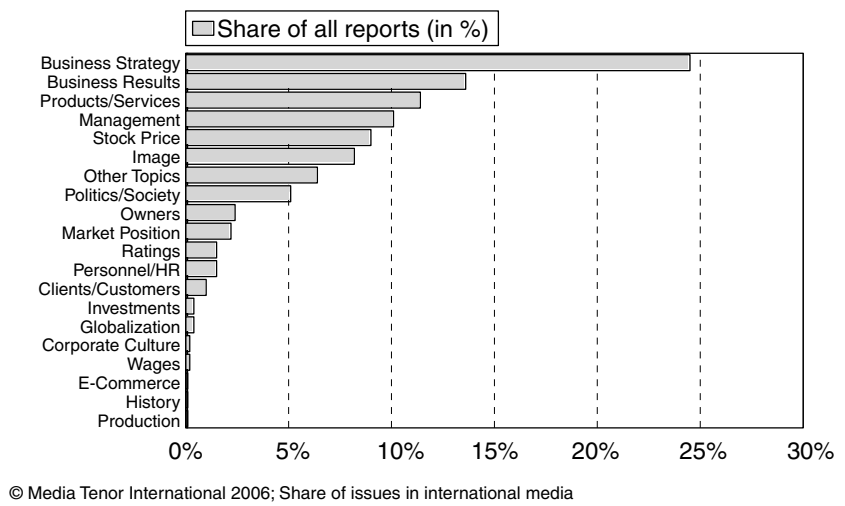

Chart 6. Topics of media coverage on the insurance industry.

issues that are picked up by the media and the issues which are underreported. Media Tenor has done surveys among business journalists in Germany and Switzerland to find out what industries and topics in their opinion deserve more media coverage. Insurance and banking rank high on this list because of the forthcoming demographic challenges of an ageing workforce that will need financial support for retirement. These journalists also want to focus more intensively on human resources, management and client relations. At the same time, they would like to cut back coverage of earning figures or balance sheets. As discussed below, this shows that journalists understand the drivers of shareholder value that produce bottom-line financial results.

However, looking at the media coverage in Germany, Austria, France, Italy, Spain, the U.K., the U.S. and South Africa, journalists are still far away from giving the key value drivers the attention they deserve. Most of the 2005 coverage is linked to business strategy (e.g., mergers and acquisitions, joint ventures and selling of assets) and business results. And while management in general garnered significant attention, the reporting on human resources - apart from layoffs - and client relations is negligible.

When journalists know how important various topics are but do not adequately cover them, what is the reason? From communication's science, we know that there are two basic reasons for this. The first is "prominence," which is the fact that the media focus on dramatic topics that are of interest to a broad range of readers. Examples here are mergers, acquisitions and big strategic actions taken by market leaders. The second is "negativism," which is the fact that the public has more interest in negative stories than positive ones and so the journalists give these more attention.

A third plausible reason of non-reporting might be the lack of sufficient information offered by corporations on the relevant value drivers. With regard to the insurance industry, the loss ratio has been established as one of the most important concepts for measuring operational performance. Nevertheless, the loss ratio is about the past and there is no guarantee that tomorrow's loss ratio will be the same as today's. A single hurricane in a densely populated area can change everything. Thus for $\mathrm{P} \& \mathrm{C}$, as well as 
Table 1 CFOs' perception of the relative importance of performance measures in the global insurance industry

\begin{tabular}{|c|c|c|c|c|c|}
\hline Strategy & Customers and & People and & Risk managem & tFinancial position & Financial \\
\hline Plans for growth & $\begin{array}{l}\text { Customer } \\
\text { retention }\end{array}$ & $\begin{array}{l}\text { Quality of } \\
\text { management }\end{array}$ & $\begin{array}{l}\text { Risk } \\
\text { management } \\
\text { practices }\end{array}$ & $\begin{array}{l}\text { Capital } \\
\text { management }\end{array}$ & Expense ratio \\
\hline $\begin{array}{l}\text { Distribution } \\
\text { channels }\end{array}$ & Market growth & & $\begin{array}{l}\text { Asset/liability } \\
\text { management }\end{array}$ & $\begin{array}{l}\text { Investment } \\
\text { performance } \\
\text { Capital adequacy }\end{array}$ & $\begin{array}{l}\text { Performance by } \\
\text { business segment } \\
\text { Earnings } \\
\text { Return on risk- } \\
\text { adjusted capital }\end{array}$ \\
\hline
\end{tabular}

Measures: $90 \%$ or more of CFOs surveyed perceive a measure to be particularly important in managing the company.

Source: PwC "Value and Reporting in the Insurance Industry" by Robert G. Eccles and Michael P. Nelligan.

life and health insurance, it could be much more meaningful to focus on the client recommendation ratio, the client retention ratio or the client "share-of-wallet" ratio.

\section{Concept and aim of "ValueReporting"}

Substantial evidence exists that companies are indeed not reporting sufficiently about value drivers that shareholders and other stakeholders - and the companies themselves - consider important in building the value of an insurance company. For example, a survey conducted by PricewaterhouseCoopers ${ }^{12}$ lists 29 key financial (e.g., expense ratio, earnings, embedded value, return on risk-adjusted capital and claims ratio) and non-financial (e.g., quality of management, customer retention, customer penetration, employee satisfaction and brand equity) performance measures that are critical to managing an insurance company. Executives in 26 large insurance companies in the U.S., Europe, Canada and Australia were asked to evaluate how important each of these measures was in managing the company, how actively they reported information on this respective measure and how reliable the information was for reporting performance on this measure. At the same time, 51 large institutional investors and 36 sell-side analysts were surveyed to get their views on how important each of these measures was and the extent to which they were getting good information on them from insurance companies.

The survey results were very telling. All three groups - company executives, investors and analysts - regarded a broad range of financial and non-financial measures as important for creating shareholder value. For example, over 90 per cent of company executives regarded the measures in Table 1 as particularly important. Investors and analysts had similar views, although there were also some differences, such as company executives regarding employee satisfaction as more important than

\footnotetext{
${ }^{12}$ Eccles and Nelligan (1999).
} 
analysts and investors. Conversely, analysts and investors regarded fee-based revenue growth as more important than did company executives.

Of more importance, analysts and investors did not believe they were getting sufficient information from companies on a number of value drivers they regarded as important, resulting in a number of significant "information gaps." The most important information gaps were in the areas of customers (e.g., customer retention and customer penetration) and employees (e.g., quality of management) - topics that journalists in the Media Tenor survey identified as deserving more attention. In most cases, these information gaps exist due to "reporting gaps" in these companies. While recognizing these value drivers as important, companies admit to not actively providing information on them. This is the case for customer retention and customer penetration. Companies also admit to not providing much information on employee satisfaction although, as noted above, this is not something that analysts and investors care about very much. In contrast, companies think they are doing a good job of providing information on quality of management, but analysts and investors clearly do not agree.

Company executives give a number of reasons for not providing information on key value drivers. One of the most common ones is that doing so will provide information to competitors that will hurt the company's ability to create value for its shareholders. This is often a dubious argument since examples can usually be found of at least one company providing information another considers proprietary. Furthermore, analysts and investors have a number of legitimate ways to gather information they think is important if companies are not providing it. When this happens, however, the broad public does not have this information and this puts the company's reputation at risk.

A more legitimate reason for not providing information is that it is of dubious reliability due to "quality gaps" in the company's information systems. The PwC survey found a number of quality gaps including customer retention, customer penetration, employee satisfaction and quality of management. If company executives should therefore decide to start providing information on these important nonfinancial value drivers, they will first have to develop good measures and systems for providing this information.

\section{The benefits of better corporate communications for companies, shareholders and other stakeholders}

In the $\mathrm{PwC}$ survey of the insurance industry discussed above, company executives were asked whether their companies' share prices were properly valued. Only 35 per cent thought they were and all the rest thought their shares were undervalued. However, since markets set prices based on information, how can the market properly value a company's shares if it is not getting the information necessary to do so? Thus, it is in the self-interest of companies to provide more information on key value drivers, particularly the non-financial ones concerning customers and employees. This will contribute to more accurate stock prices. When the company's underlying performance is stronger than what is reflected in short-term financial results, its stock price will be higher. 
Providing more information is also important from a reputational risk point of view. While companies cannot completely shape the media agenda for reporting on the insurance industry, they can certainly influence it. Right now they have an opportunity to do so since the media is not preoccupied with prominent and negative events like scandals and investigations. There is a window of opportunity for the industry to improve the media's understanding of it and, as a result, to improve the understanding and perception of the industry by the public. Doing so will lay the foundation for a strong reputation that can withstand negative future events and negative media coverage which are inevitable. The enormous benefit here is that although bad news hurts stock prices, when the image is a strong and a mostly positive one, the damage will be much less and the stock price recovery will be quicker.

Finally, there is a third important benefit to providing more information to shareholders and the media. As the old saying goes "what gets measured, gets managed." Thus measuring and reporting about value drivers regarding customers and employees will create a clear incentive for insurance companies to do a better job of managing them. They will want to report good news and in order to do so they will have to do a good job managing these critical value drivers. The result of better management and better external communications will be more positive media coverage and a stronger positive industry reputation. Failure to act will leave the industry at the mercy of future events and of how the media decides to report about them.

\section{References}

Cohen, B.C. (1963) The Press and Foreign Policy, Princeton, NJ: Princeton University Press.

DiPiazza, S.A. and Eccles, R.G. (2002) Building Public Trust: The Future of Corporate Reporting, Hoboken, NJ: John Wiley \& Sons.

Eccles, R.G. and Nelligan, M.P. (1999) Value and Reporting in the Insurance Industry, New York: PricewaterhouseCoopers.

Eccles, R.G., Herz, R.H., Keegan, E.M. and Phillips, D.M.H. (2003) The ValueReporting Revolution: Moving Beyond the Earnings Game, Mülheim: Vch Verlagsgesellschaft Mbh.

Financial Times Deutschland (2003) 'Mannheimer wähnt sich in Sicherheit', 1 August 2003, p. 10.

Frankfurter Allgemeine Zeitung (2003) ‘Der Gerling-Konzern hat 2002 sein Eigenkapital verloren', 4 August 2003 , p. 13.

Handelsblatt (2005) 'Allianz droht Rechtsstreit', 25 November 2005, p. 26.

Insurance, Finance and Investment (02.05.2005) 'Munich re, converium subpoenaed by US Attorney General', 2 May 2005, p. 4.

Schanz, K.-U. (2004) 'Issue management in (Re)Insurance: An emerging strategic challenge', The Geneva Papers on Risk and Insurance — Issues \& Practice 29(2): 334-341.

Stuttgarter Zeitung (2003) 'Die Mannheimer Leben ist vorerst gerettet', 15 July 2003, p. 10.

Vollbracht, M. (2005) 'Imageschaden à la Spitzer möglich', Media Tenor 12(150): 50-51.

\section{About the Authors}

Matthias Vollbracht is a co-founder and partner of Media Tenor GmbH. He has worked as a business journalist before starting at Media Tenor in 1994. Leading the business and economics research department, he has more than 11 years of experience in consulting companies, NGOs and think tanks regarding their media reputation and communication strategy. Matthias Vollbracht holds a diploma in economics from the University of Mainz. 
Dr. Robert G. Eccles is a co-founder and Managing Director of Perception Partners Inc. Prior to founding Perception Partners, Dr. Eccles was a tenured professor at Harvard Business School where he was a member of the faculty for 14 years. Dr. Eccles received a S.B. in Mathematics and a S.B. in Humanities and Science from the Massachusetts Institute of Technology in 1973. He received an A.M. (1975) and Ph.D. (1979) in Sociology from Harvard University. 